\title{
Journalists in Parliaments. Three cases concerning the accessibility of legislatures in Central Europe
}

\author{
prof. Péter SMUK PhD.
}

\begin{abstract}
In modern legislatures, the public nature of political debates has been achieved as a constitutional principle. Constitutions and parliamentary standing orders provide with possibilities for journalists and media to access to sittings of the legislatures in order to offer the public the information on issues debated in parliament. Against this normative background, this paper introduces three cases (from Macedonia, Poland and Hungary) where journalists' work have been limited in legislatures for several reasons. The paper considers also the competing values of freedom of information, freedom of expression visa-vis the dignity and undisturbed functioning of parliaments.
\end{abstract}

\section{Keywords}

constitution, journalist, legislatures, parliament, Hungary, Macedonia, Poland

\section{The normative background - the public nature of parliamentary debates}

\section{Parliaments and the public - a historical and theoretical framework}

Based on the deliberative concept of democracy, the constitutional theory might focus on the spread of political discourses in society and the search for consensus based on the free and active participation in public debates. Those criticising the model of Habermas call attention to the fact that several deliberative preconditions for an ideal political discourse and democracy are met in actual terms through representatives in an institutional framework, in the representative bodies. ${ }^{1}$ When taking account of the various

1 The thought of Jürgen Gerhards is referred to by: POLYÁK, Gábor: Párhuzamos valóságok. Az Alkotmánybíróság nyilvánosság- és médiaképe társadalomtudományi eredmények tükrében [Parallel realities. The publicity and media through the eyes of the Constitutional Court, in the context of the achievements of social sciences], in: Fundamentum, 16, 2012, 4, 24. 
arenas of political debates, the bodies of representation, especially the Parliament, are obviously indispensable. Through the victory of representative democracy, "politics" as a concept "describes the sort of debate and discussion that takes place in legislatures; its procedures allow for participation, discussion, and, potentially, compromise. Political processes are suited to the consideration of all potentially relevant aspects of a decision", even if - certainly -, one of the most important of these is the reference to "the people". ${ }^{2}$ The manifestation of political pluralism in the Parliament takes the form of the presence of governing and opposition parties. It is important to note that the driving force of political debates is the opposition, by performing its functions. ${ }^{3}$

The transformation of feudal representative parliaments into civil bodies of popular representation meant, among others, the turn, which Habermas describes as follows: as of the $18^{\text {th }}$ century, the discourse of "arguing citizens" and parliamentary debates were linked. He is of the opinion that the new leading stratum of capitalism (in England), "without now being represented in Parliament, formed something like a steadily expanding pre-parliamentary forum. Here, as a critical public soon to be aided by appropriate publicist organs, they followed the deliberations and decisions of Parliament, regardless of whether they still had for the most part the vote, as in London and Westminster or whether (as elsewhere) they were part of the disenfranchised mass. Parliament's change in function was not reducible solely to the fact that the sovereign, bound by the Bill of Rights, was demoted to a King in Parliament. In addition, it took the new relationship of Parliament to the public sphere that ultimately led to the full publicity of the parliamentary deliberations to bring about a qualitative difference from the previous system." We may remark that it was only in 1803 that the Speaker officially authorised journalists to stay in the chamber (in the gallery). However, Habermas in his historical overview also discusses the modern development relevant for us, according to which, as a result of the broadcasting of parliamentary sittings, MPs stopped talking to one another; they indeed address the "audience". Parliamentary debate transforms into a show, critical dialogue turns again into representative demonstration and arguments are replaced by symbols. ${ }^{4}$ However, recently this has raised few problems regarding the constitutional guarantees of the relationship between the parliamentary representation and the public; as we will see, constitutional practice, irrespective of this observation, takes the course leading towards full publicity.

Popular sovereignty prevails through participatory rights and these rights are to be fed by the information necessary for well-informed decisions. We can present this relationship through the guarantees of the parliamentary procedures and their public nature because, these create the forum of political debates and the link between parliamentary debates

2 SCOTT, Paul: (Political) Constitutions and (Political) Constitutionalism, in: German Law Journal, 12, 2013, 2164.

3 SMUK, Péter: Ellenzéki jogok a parlamenti jogban [Rights of the opposition in parliamentary law], Budapest 2008 and CDL-AD(2010)025.

4 HABERMAS, Jürgen: The Structural Transformation of the Public Sphere. An Inquiry into a Category of Bourgeois Society, Cambridge - Massachusetts 1991, 62-63, 206; and BEYME, Klaus von: Die parlamentarische Demokratie. Entstehung und Funktionweise 1789-1999, Wiesbaden 1999, 275. 
(information) and the public. The Council of Europe adopted a recommendation on the description of the latter as early as in $1997 . .^{5}$

The Council of Europe observed that the parliaments had a great difficulty in trying to remain the key actors of the democratic institutional system, and wanted to provide a solution for that problem. According to the Council of Europe, the modern tools of mass communication need to be used to bridge the gap between voters and representatives. Difficulties are obvious: the media prefer to entertain, the government is in a privileged position as compared to the legislative body, because it can "use" the media for its own purposes faster and more professionally, etc. As a result, the Council of Europe comes to the conclusion that the most important fora for public debates do not include parliaments anymore, and this, according to the recommendation, entails the risk of citizens starting to use other forms of mediation in order to express popular will. Amongst the specific recommendations of the Council of Europe, we find the guarantees of the publicity of parliamentary work as broad as possible, covering also the work of committees, the improvement of the working conditions of parliamentary correspondents, and the establishment of on-line communication tools for journalists and for citizens in general; support must be given for setting up media channels dedicated to covering the work of parliaments.

As regards the public nature of parliamentary work, opinions diverge. According to the critical position of Habermas in modern parliaments that have changed the free mandate into illusion, members of parliament do not wish to convince one another but make statements for the public. This is not only by chance that permanent television broadcasting started to spread only towards the end of the $20^{\text {th }}$ century: permanent television broadcasting of parliamentary sittings are allowed as of 1979 from the USA House of Representatives, as of 1986 from the Senate and as of 1989 from the House of Commons of the British Parliament.6,7

Main functions of parliamentary publicity are to ensure legitimacy and enhance control over government and politicians. In the course of the debates in plenary or committee meetings, the opposition parties can force the government to come up with arguments or at least underpin its decisions; furthermore, it might reveal issues and information for the public. These questions and answers inform the public about the state of public affairs and the performance of the government. As the Hungarian Constitutional Court put it: "free parliamentary debate contributes to voters being able to have a proper picture of the activities of MPs and other officials holding high public offices and enables them to participate in political discourse and decision-making equipped with adequate

5 RES. 1142 (1997) on parliaments and the media.

6 MCKAY, William - JOHNSON, Charles W.: Parliament and Congress: Representation and Scrutiny in the Twenty-First Century, Oxford 2012, 101-105.

7 Sir Barnett Cocks, the Clerk of the House, in 1963: "The press, constitutionally and historically, is here on sufferance. That is the position. Whatever recognition you have, on a lobby basis and so on, seems to be grudgingly given on pain of cancellation should the press once step out of line." - see: https://www.pressgallery.org.uk/ the-gallery-today/. 
information." 8 Therefore, publicity is the general tool of exercising control; it is its natural environment. The specific tools to obtain information in the course of parliamentary control operate within this, such as political debates, questions, interpellations and investigation committees.

For the purpose of analysing the legal institution - and the practice of the principle - of parliamentary publicity 9 , I recommend the following aspects beyond democratic legitimacy. The starting point is the general rule of public sittings generally enshrined in constitutions, and the practical implementation thereof embraces the

a) rules guaranteeing the ordering of in-camera plenary and committee sittings;

b) access to plenary and committee sittings, including:

ba) the presence of "outsiders" in the hall,

bb) the possibility of a media broadcasting of the sittings;

c) access to parliamentary papers, documents, including the operational data of the Parliament as a state body, legislative proposals and the minutes of votes and checks.

Presence in the plenary or meeting rooms embodies an obvious, direct but specific form of publicity. Those who have the opportunity to be present in person might gain direct experience of the Parliament's work and obtain certain information. However, their personal chance of obtaining information does not guarantee that the public also obtains information in practice. Due to physical constraints, these people are only a few in number and information can reach the broader public only through mediators. Mediation might take the form of reports made by the participants and/or by "broadcasting", through technical equipment, pictures, audio and video recordings from the sittings.

The specific feature of media presence, compared to the "public gallery", is that journalists, on the one hand, carry out professional activities when broadcasting sittings; on the other hand, technical equipment necessary for broadcasting is given. These allow an evaluation different from that of a personal observation made by visitors or amateur devices suitable for making recordings, pictures or videos used by them.

\section{Access to parliamentary debates - a landscape of Central European regulations}

The publicity of parliamentary business is provided by all constitutions in Europe; however, detailed provisions show some diversity. The Estonian, Polish, Romanian or Bulgarian parliamentary rules of procedure identify the public of the "gallery", whereas the Croatian Sabor designated the northern section of the gallery for visitors. In Hungary, it is the Speaker of the Parliament who might designate places for visitors and the representatives of the media. According to the parliamentary rules of procedure, visitors (the public of the gallery) are obliged to refrain from any form of expressing an opinion, agreement or dislike and

8 Constitutional Court decision No. 50/2003.

9 As the basis of the constitutional interpretation, see MAGIERA, Siegfried: Art. 42 [Öffentlichkeit, Mehrheitsprinzip, Berichterstattung], in: Grundgesetz Kommentar, SACHS, Michael, München 2011, 1253-1258. 
generally from interrupting the session. ${ }^{10}$ The Act on the publicity of the Croatian Sabor lists specific forms of conduct considered as disturbing and therefore not permitted, such as: applause, loud talk, use of mobile telephones, holding placards, taking photographs, "etc." (Article 4 (3)).

The right of broadcasting the sittings is recognised in all examined countries without any exceptions. Parliamentary rules of procedure enshrine the right of broadcasting and information concerning journalists' accreditation and codes of conduct similar to the one described above. Parliaments themselves have professionalised the relations with the media by establishing organisational units responsible for press relations and communication.

In the Estonian Parliament film and video recordings and television and radio broadcasts of sittings may be made and photographs of sittings may be taken with the permission of the President of the Riigikogu (Rules of procedure, Article 59). The Presidium of the Lithuanian Seimas regulates the proper rules of procedure and provides for the broadcasting in line with the agreement concluded with national radio and television (Article 131). However, the rules of procedure declare the official recordings of the Parliament to be available for all media service providers and allow further recordings to be made from the designated gallery. While the rules of procedure of the Polish Sejm makes presence on the gallery conditional upon the Marshal's permission, the presence of the media is not subject to such permission (Article 172, section 1, 2-3). An interesting rule in the Czech Parliament, which also has its own audio-visual network, is that the plenary session might allow the media representative to be present during in-camera meetings (Article 56).

The Hungarian Act on Parliament (Act XXXVI of 201211) includes detailed rules on media presence; after earlier constitutional debates it maintains the priority of the close circuit broadcasting and enshrines principles that provide guarantees (Article 59). Under the terms of the law, for the purpose of broadcasting the Parliament's sittings and certain committee meetings, a closed circuit audio-visual system is put in place, which is available to media service providers; it can be followed on-line and its recorded broadcasts should be made available in archives, as well. This broadcast is without prejudice "to the right of any media service provider to broadcast or record a program from a place designated by the Speaker in the House of Parliament. The Speaker can only designate a place for the purpose of broadcasting or recording a program that does not prevent the conditions for free dissemination of information necessary for the formation of democratic public opinion." The public sittings of the parliamentary committees not broadcasted by the closed circuit system may be broadcasted or recorded by the media service provider. The technical preparations of the broadcasting and its proceeding shall not disturb the sitting of the committee. Under the terms of the Act on Parliament "The aim of video broadcasting the sittings of the Parliament and of the parliamentary committees shall be

10 Sources of explicit parliamentary rules of procedure provisions: Latvian, Article 78, Czech, Article 20, Slovakian, Article 21, Hungarian Act on Parliament 55 (2) and 58 (1), Romanian Chamber of Deputies, Article 140 (4), Romanian Senate, Article 117 (3), Bulgarian, Article 45 (3).

11 Online: http://www.parlament.hu/documents/125505/138409/Act+XXXVI+of+2012+on+the+National+Assembly/b53726b7-12a8-4d93-acef-140feef44395. 
to provide impartial, balanced, accurate and factual information for the viewers about the activity of the Parliament. The television broadcasting shall be in line with the activity of the Parliament, focusing on the actual events and the work of the Parliament, in particular the chair of the sitting, the actual speakers, the presentation of the results of the vote, the floor as a whole, and other events that take place on the floor. The video editing shall be objective and factual, in line with the proceeding of the sitting."

In the Lithuanian Seimas the press office organises the press conference of MPs and the rules of procedure prescribe the obligation to provide at least two press conferences a week for opposition parties (Article 132). According to the Croatian rules of procedure (Article 288), press conferences possess multiple layers on the activities and the results of the Sabor; press conferences can be held based on the decision of the plenary, the Presidium or the Speaker, whereas press conferences on committee meetings can be organised on the basis of the decision taken by the chair of the given committee. In addition, parliamentary groups might also hold press conferences with no limitation.

\section{When presence of journalists is uncomfortable - recent cases of limitation of media correspondence from Central European parliaments}

Below we will look into three cases from Central European countries, which are connected to the limitation of journalists' work in the parliament. The particularity of these cases lies in that media publicity became uncomfortable for the parliamentary majority (and its speaker of the parliament) in certain situations. Although the publicity of parliamentary sessions and the relatively free parliamentary work of journalists are applied as a principle by the constitutions, the parliamentary rules of procedures and the political culture of each country, and it has been "practiced" for over 25 years - yet the speaker of these parliaments resorted to limit this freedom. A common feature in the debates below is that legislation has a sort of "official" publicity, independent media, however, are affected by limitations.

\section{Case of Macedonia (Case of Selmani and Others v. the former Yugoslav Republic of Macedonia, 2017)}

The first case drawing Europe's attention took place in the Macedonian parliament, and the journalists concerned took their case to the national constitutional court as well as to the European Court of Human Rights. Findings of the Court is as follows. ${ }^{12}$

The plaintive journalists were removed from the gallery of the plenary session on 24 December 2012. Before the removal, the parliament had been discussing the budget law of the following year and amid a fierce political debate representatives of the opposition occupied the pulpit of the speaker of the parliament. In the plenary session hall, a little scuffle began while in front of the parliament threatening demonstrators appeared. The

12 Case of Selmani and Others v. the former Yugoslav Republic of Macedonia, Par. [5]-[15], online: http://hudoc. echr.coe.int/eng\#\{"itemid":["001-170839"]\}. 
speaker of the parliament ordered to empty the hall in order to restore the parliamentary rules of procedure and also ordered to empty the gallery to guarantee the safety of the journalists. Then after some resistance, the media workers were led to a press room by the employees of the security service where they could follow the events of the hall and, after the order had been restored, the continuing plenary session on television. According to the complaint of the journalists, their safety was not jeopardised and they did not need any special protection neither against the opposition MPs in the plenary session hall nor against the demonstrators in the street. In their opinion, however, their removal took place without an acceptable legal base and justification infringing their right to follow the events at the plenary session and report them to the public. The press room and the official television broadcast could not provide all information on the events thus infringing their right to freedom of expression provided by Article 10 of the European Convention on Human Rights. ${ }^{13}$ In the Macedonian law, the Constitution provides the publicity of parliamentary sessions (article 70) although the ECtHR failed to make any reference to this. The detailed rules on the press publicity of legislation are laid down in the parliamentary rules of procedures and the parliamentary act. The Court found the latter legal source a sufficient legal background with regard to judging the case including actions of the authorities. ${ }^{14}$ The Court argued that it serves a legitimate interest if the speaker of the parliament exercises law enforcement and disciplinary rights to protect parliamentary procedures. In the present case, the Court considered the following two justifications both based on public interest: Is the protection of parliamentary procedures and the (public) order of the plenary session stronger or that of informing the public via the journalists' activity? The judgement of the case depended on whether the evaluation of the situation and actions of the authorities were lawful, justified and proportionate. [Par. 75-76] The Court took it as a starting point that in other cases it had stipulated that the removal of journalists from the site of demonstrations or riots required special investigation and thorough justification, therefore it would have expected strong arguments from the authorities in the present case. Namely, the debated actions of the authorities adversely affected the "watch-dog" role of press through which the press reporting on authorities' actions also performs its function to control the power. [Par. 75] In the present case the Macedonian government was not able to confirm the jeopardising nature of either the riot outside the parliament or the scuffle in the plenary session hall. Although they referred to uncertain information concerning the attack against the parliament building by the demonstrators outside, the journalists were not taken out of the building but only to a different room. [Par. 78] Although a group of the opposition disturbed the legislation procedure by appearing on the pulpit of the speaker of the parliament and throwing some objects, these events, however, happened in a physical space clearly separated from the gallery. The journalists were passive observers, nothing was found to support the fact that the throwing of objects could jeopardise their bodily

\footnotetext{
13 Note that plaintiffs disapproved of the procedure of the national constitutional court in their case since no hearing was provided for them. The Court accepting the complaint ruled that Article 6 (1) of the Convention had been infringed.
}

14 Ibidem, Par. [16]-[23], [67]. 
integrity. [Par. 80, 83] When emptying the gallery the employees of the security service faced some resistance because plaintiffs first refused to obey and leave the galley. This, however, was not considered serious by the Court to such an extent that would influence the judgement of the authorities' actions (anyway no procedure was started against an alleged injury of any security guard). [Par. 81] According to the Court the public must have taken special interest in the events, therefore the media broadcast of the events had particular significance. However, the removal of the journalist made them unable to perform such activities:

\begin{abstract}
"the applicants' removal entailed immediate adverse effects that instantaneously prevented them from obtaining first-hand and direct knowledge based on their personal experience of the events unfolding in the chamber, and thus the unlimited context in which the authorities were handling them (...). Those were important elements in the exercise of the applicants' journalistic functions, which the public should not have been deprived of in the circumstances of the present case. Against this background, the Court considers that the Government failed to establish convincingly that the applicants' removal from the gallery was necessary in a democratic society and met the requirement of "pressing social need"." [Par. 84-85. emphasis on italics added]
\end{abstract}

\title{
Case of Poland
}

As mentioned above, the parliamentary rules of procedures of the Polish Sejm guarantee that legislation is public with special respect to the presence of press. Within this framework, the Marshal (speaker) has defined the order of admission to the building of legislation as well as the rules on where MPs, visitors and the media can enter. The "ordinance on admission to the buildings administered by the Chancellery of the Sejm and admission and entry to the remaining areas administered by the Chancellery of the Sejm" has been amended on 19 May 2017. The relevant rules read as follows:

\footnotetext{
"The Information Centre of the Sejm of the Chancellery of the Sejm will familiarize journalists and persons, they deal with technical support related to professional activities by journalists, with ordinances in force in buildings." "In justified cases, with respect to maintaining peace and order, and ensuring the security of the Sejm and the Senate, [it is possible to] refuse to issue the [entry] documents ... [This rule] ... shall apply in particular where it is found that a person, in favour of the document to be issued did not comply with the rules in the past; or disturbed the peace and order in the buildings or violated the prestige of the Sejm or Senate, good customs or grossly violated the right to privacy of others." (§§ 19-20)
}

"1. Press cards allow holders to move freely around areas and buildings, excluding the Plenary Hall and the lobby of the Plenary Hall during sessions and the House of Deputies, with the exceptions stipulated in the para 3.

2. Press cards for media technical personnel allow them to move freely around areas and buildings, excluding the Plenary Hall and the lobby of the Plenary Hall during sessions and the House of Deputies, with the exceptions stipulated in the para 3. 
3. Persons to whom a press card or a press card for the media technical personnel has been issued may access:

1) the Conference Room in the House of Deputies;

1a) the meeting rooms of parliamentary committees in the House of Deputies - through entry FVIIIA;

2) other areas in the House of Deputies - after submitting their personal data to the member of the Marshal's Guard at the F1 entrance by a deputy or the senator - when accompanied by a deputy or senator; the provision of $\S 5$ para. 4 applies accordingly...." (§ 40.)

"1. Persons who are in the gallery are obliged to use separate places for them and remain silent and serious, in particular, refrain from expressing support or disapproval of the ongoing plenary session through applause or any other form and they also have to obey the Marshal's Guard commands in the field of order and security.

2. In case of violation of the principles set out in paragraph 1. Parliament Speaker may order to leave the gallery partly or completely (...)" (§ 65.) $)^{15}$

The case of the limitation of journalists' work in 2016, which according to some interpretations ${ }^{16}$ constituted an organic part of the Polish constitutional debate (or crisis), needs to be reconstructed by us, no court case is available. ${ }^{17}$ The speaker ("Marshal") proposed new rules on the work of media representatives in the building of legislation in the middle of December 2016. As the previous practice in use since the change of the political regime (the whole building of legislation was accessible for journalists) was found "chaotic" by the heads of the Sejm, the proposal with an official justification aimed to change this. ${ }^{18}$ Accordingly, journalists' access to the building of legislation and audio-visual recordings would have been limited especially in the plenary session hall (on the public gallery):

- Each media organisation is to be allowed to accredit two representatives;

- Journalists will be allowed to report on the parliament from one location;

- Journalists will not be allowed to record plenary proceedings from the public gallery, or to record meetings of parliamentary committees;

- Journalists will be permitted to enter the parliament's public gallery only after "prior notification" to the parliament's administration;

15 ZARZĄDZENIE NR 1 MARSZAŁKA SEJMU z dnia 9 stycznia 2008 r. w sprawie wstępu do budynków pozostających w zarządzie Kancelarii Sejmu oraz wstępu i wjazdu na tereny pozostające w zarządzie Kancelarii Sejmu, online in Polish: http://www.sejm.gov.pl/kancelaria/zarz1_2008.pdf.

16 See: "Open Letter to the College of Commissioners regarding the situation in Poland", online: http://www.aedh. eu/IMG/pdf/Joint_NGO_letter_to_the_European_Commission_on_Poland-24.02.pdf and its Annex, online: https:// www.fidh.org/IMG/pdf/annex_to_joint_ngo_letter_to_the_european_commission_on_poland-16_feb_2017.pdf.

17 The report and opinion of the Helsinki Foundation in Polish is online: http://www.hfhr.pl/wp-content/uploads/2017/01/Opinia_HFPC_11012017.pdf. I am grateful for Dorota Głowacka (Coordinator of the Observatory of Media Freedom in Poland, Helsinki Foundation for Human Rights) and Łukasz Młynarkiewicz (lawyer and legal counsel) for the information provided about the issue.

18 The Polish Government's response to the concerns expressed in relation to the proposal of changes to the rules governing journalists' work in the Sejm and Senat, online: https://rm.coe.int/16806d8de4. 
- Journalists will be permitted to watch transmissions of proceedings in plenary session and committee meetings from the conference room ${ }^{19}$ in building $F$ (building $F$ is removed from the main Parliament buildings). ${ }^{20}$

The announcement of the proposal triggered an intense protest of the MPs of the opposition in the plenary session hall (and also civil organisations protested in the street in front of the parliament). An opposition MP taking advantage of his speech at the budget law debate held up a 'Free media in the Sejm' sign and ignored the speaker's instructions to leave the rostrum. Then the Marshal taking disciplinary action excluded the MP from the rest of the session. A number of the opposition party 'Civic Platform' deputies then occupied the area around the podium and conducted a sit-in holding up similar signs, demanding that the excluded deputy be re-instated and blocking work on legislation. Following a recess lasting several hours, the Sejm session was re-convened in an ancillary hall outside the main chamber and deputies from 'Law and Justice', which holds the parliamentary majority, and a handful of opposition members approved the 2017 budget. ${ }^{21}$ Several MPs were absent from the voting, let alone no journalists were allowed to be present - however the Marshal insisted that the public nature of debates has been guaranteed via Sejm cameras and internet broadcasting. ${ }^{22}$ According to the opposition, the budget law was passed in violation of relevant rules because not even the quorum was verifiable (voting took place by holding up hands instead of using electronic voting machine), at the same time, however, the governing party persisted in the proposal for the new media rules. In the beginning of 2017, amid further national and European protests the speaker withdrew his proposal, nevertheless according to press reports, journalists were not able to enter the building of the Sejm on several occasions. ${ }^{23}$

\section{Case of Hungary}

As we saw above, the act on the Hungarian parliament advocates the publicity of legislation in the interest of democratic public opinion at the same time ensuring the

19 A new Media Center has been set up: http://www.sejm.gov.pl/media8.nsf/files/EPIA-AGMN5J/\%24File/Informacja\%20na\%20temat\%20zmian\%20w\%20organizacji\%20pracy\%20medi\%C3\%B3w\%20w\%20Parlamencie.pdf.

20 Association of European Journalists - In Poland, media freedom fears persist as new plans restricting journalists' access to parliament to be unveiled in January, online: http://www.aej.org/page.asp?p_id=569.

21 SZCZERBIAK, Aleks: How will Poland's parliamentary crisis develop? - The Polish Politics Blog, online: https:// polishpoliticsblog.wordpress.com/2017/01/03/how-will-polands-parliamentary-crisis-develop/.

22 Statement by the Marshal of the Sejm of the Republic of Poland on the course of the 33 $3^{\text {rd }}$ sitting of the Sejm on 16 December 2016, online: http://www.sejm.gov.pl/sejm8.nsf/komunikat.xsp?documentld=4F557DA5DFD6BCA3C1258092002B3A9C.

23 Polish protesters block parliament over press freedom - BBC News, online: http://www.bbc.com/news/ world-europe-38347674. The statement of the Helsinki Foundation "on still unclear rules for media in Parliament" at http://www.hfhr.pl/en/hfhr-on-still-unclear-rules-for-media-in-parliament/. Further suspension took place between 14-21 July 2017; affecting the admission to buildings administered by the Chancellery of the Sejm, to persons whose admission and entry were granted on the basis of one-time entry cards and registered letters. This was connected to protests that occurred before parliamentary hearings on changes to the law on the National Council of the Judiciary and the Law on the system of common courts. See: https://oko.press/kuchcinski-zamknal-sejm-obywateli-wejda-najblizsze-dla-posiedzenie/. 
speaker to set out details (on designating a working area for media employees).

The Speaker's ordinance no. 9/2013 - in the framework of the principles laid down by the Act on Parliament - limits the possibilities for private broadcasting and the working area of journalists. ${ }^{24}$ Although the press has a designated gallery in the plenary room, the Speaker has prohibited the private video recordings in the plenary and on the corridor around it (Art. 8.1a of the Ordinance). Journalists can work on and broadcast from only the designated corridors and rooms of the building (see Art. 8.1d).

In 2015 and 2016 the speaker through debated measures, by the suspension of journalists and even the press accreditation of whole editorial offices, enforced his constitutional authority to "ensure undisturbed operation of the National Assembly and to preserve its dignity, the Speaker of the National Assembly shall exercise policing and disciplinary powers". (Fundamental Law Art. 5 par. 7) ${ }^{25}$ The speaker took his unique decisions driven by the conviction that media workers not only disturb the peaceful legislative function of MPs but also some interview making methods and footages recorded in the Parliament undermine the prestige and dignity of the National Assembly. ${ }^{26}$ Journalists of commercial media providers and internet news sites objected to this measure of the speaker because it imposed too narrow limits on their work. The limitation of available area is - in their assessment - in contradiction with the abovementioned ruling of the Parliament Act (Art. 59.3). The accreditation withdrawal in question was based on pushing the limits of this narrow area: journalists moved beyond the designated area "chasing" brisk walking MPs through corridors not allowed for them to enter.

Journalists' access to the building of Hungarian legislation has been narrowing over the past decades. ${ }^{27}$ While earlier there were not any restrictions on meeting and interviewing MPs on corridors as well as (depending on the space available) reporting on and broadcasting the plenary session of the National Assembly, likewise in Poland, and then a series of limitations appeared. The publicity of corridors narrowed (by closing down some areas), and the location/designation of the press gallery was a recurring problem. Soon the broadcast of sessions came to an end because only the right to take over the official CCTV broadcast remained. Thus the possibility of alternative broadcast of sessions by the media was over. According to journalists, the official broadcast includes some elements of the parliament's operation (speeches etc.) while other events are necessarily excluded.

24 Speaker's Ordinance no. 9/2013 on the rules of entry to and stay on the premises of the Parliament, the office block of the National Assembly and the buildings for the National Assembly Office, online: http://www. parlament.hu/documents/10181/11066/2013r09.pdf/1940811a-f4bd-44b4-95fc-871924b07a28; excerpts at http://www.parlament.hu/a-sajtotudositas-rendje; illustrated: https://444.hu/2016/04/26/pontosan-ennyi-lehetoseg-van-politikusokat-kerdezni-hogy-kover-laszlo-ne-tiltson-ki.

25 Online: http://www.parlament.hu/documents/125505/138409/Fundamental+law/73811993-c377-428d-9808 -ee03d6fb8178.

26 A journalist of hvg.hu was banned from Parliament, online: http://hvg.hu/itthon/20160426_Kitiltottak_a_hvghu_munkatarsat_a_Parlamentbol, also TAMÁS, Fábián: Fidesz: Journalists' behaviour is unworthy to citizens, online: https://index.hu/belfold/2016/04/27/partok_es_a_parlamenti_sajtoszabadsag/.

27 See in the theoretical framework in: SMUK, Péter: A politikai diskurzusok alkotmányjogi szerkezete [The structure of political discourses from the perspective of constitutional law], Budapest 2014, 146-147. 
Let alone the fact that the CCTV broadcast is edited, thus falling victim to the editor's subjectivity. Some events or MPs' behaviour outside the viewing angle of the official camera can be significant information for the public. The Hungarian Constitutional Court, however, ruled in its decision 20/2007. (III. 29.) $A B$ that the narrowing regulation was constitutional. In its deliberation the Court emphasised the constitutional requirements of the control of executive power and informing the public, but due to the protection of the dignity of the operation of the parliament it found the limitation of press work necessary and proportionate along the editing principles of the CCTV system (namely that it should be balanced). The Constitutional Court drew special attention to the European overview prepared by the Council of Europe which mentions two models with respect to broadcasting legislation. In some countries, the national television broadcast is exclusive while in others all media providers are allowed to broadcast. ${ }^{28}$ As to the Hungarian cases of 2015-2016, we shall be not attentive so much to the limitations of publicity of the plenary session hall but rather to the media access to the building of the Parliament dedicated for legislation, sessions, committee work and generally the activities of elected representatives and parties. The question is whether similarly to the publicity of the plenary session hall there is a strong constitutional interest in (or fundamental right to) the publicity of corridors. This question will be answered below in the light of three cases presented.

\section{Conclusion}

The constitutional functions of journalists' presence in the parliament are listed as follows:

- access to information of general interest - the operation of legislative bodies and the MPs' activities are full of information of general interest. Journalists can receive first-hand information about the work and opinion of MPs. Political debates, as well as information on state organs, make voters aware of the standpoint of parties and MPs.

- informing public opinion - public opinion can gain some information with their own sensory organs about the work of MPs and parliaments, however parliamentary publicity would not work without journalists having professional knowledge and equipment for collecting, systematising and forwarding information. It is also true for the "official", "state" broadcast of sessions. Voters would not be informed about some legislative details without journalists questioning MPs in parliament. This possibility, providing there is critical journalism, goes beyond the Habermas-problem outlined at the beginning of this paper; here MPs cannot only be "revealers" of their party's standpoint. These two functions, as well as freedom of the press and information, are embraced by the fundamental right to freedom of expression and the constitutional value of the development of democratic public opinion.

- control - media presence make MPs take actions knowing that voters (possessing the most severe sanction) can track them. As to media pluralism, the competing descriptions and interpretations of reality render different media broadcasts comparable and controllable. 
- legitimacy-bodies operating publicly may rest on a firm basis of democratic legitimacy. Voters are watching, which also provides continuous control and feedback, legislation and MPs' decision can be confirmed.

With respect to these functions, we can draw the following conclusions from the three parliamentary cases presented above.

\section{a) Publicity of the plenary session hall and possible limitations}

The operation of the parliament as a legislative body takes place at plenary and committee sessions. We can consider a constitutional right to access this information, which is a constitutional principle of the parliament's public operation, by at least accessing the official broadcast or verbatim minutes. (Naturally, access to the text of a bill or information of general interest on parliamentary administration is a related question.) Limitations are only possible in the case of constitutional or fundamental right interests of similar weight. Against these pillars of democratic legitimacy, only values of general interest (public safety, smooth running of parliamentary procedures) and fundamental rights (especially human life and dignity) can stand and be justified in a democratic state.

Nevertheless, there are special parliamentary buildings and session halls where wider presence of journalists and media would eo ipso disturb procedures or the prestige of the parliament, but drastic limitations on a practice in use cannot be defended (cf. Macedonian case). Even galleries of historic buildings provide sufficient room for correspondence or broadcasting made with state-of-the-art equipment (mobile phones, average cameras). Prohibition of such equipment is not too realistic and cannot be justified by constitutional requirements.

\section{b) Publicity of corridors and possible limitations}

In practice and physically, journalists and media providers can personally reach elected MPs, the members of legislation here (on corridors) the easiest. Limiting access to MPs entails limitations on access to information of general interest. Although the value of legitimacy of media presence is significant, not surprisingly, it is mainly uncomfortable for MPs of the governing party. Different forms of organised press publicity (press conference, press releases) provides shelter for also some MPs and moves publicity towards the old representative-symbolic communication.

On one side of the standpoints to be considered in the conflicts of constitutional values is whether the right to information includes the possible physical access to public institutions, naturally in line with security requirements. While we cannot challenge that no full access is granted to buildings of a ministry, media workers are persistent in fighting for the building of legislative. Though executive power needs a democratic legitimacy and control, constitutional procedures thereof are linked with the parliament or (in a presidential system) more acceptably, belong to organised press publicity. In this respect, the particularity of parliaments lies in the size of the buildings hosting them, which includes the abovementioned plenary session hall and its publicity; and also in the fact that officers in ministries are usually not responsible to publicity or voters, but the parliament is the workplace of elected politicians. 
On the other side, we need to consider whether the presence of journalists poses a risk on the operation and dignity of legislation as a constitutional body. Journalists and media workers observing the professional rules of journalism cannot pose such risks. On the one hand, dignity, security and operation of the Parliament are provided by some basic rules (accreditation, access control system, restricted areas, and rules on behaviour). On the other hand, journalists asking questions will not really influence the operation of legislation unless they physically prevent MPs from voting, interfere with the electronic system of the building or make unbearable noise in the plenary session hall etc. Therefore, the complete ban of the media from the parliament is an extremity impossible to defend, however, the relation between the designated area for media workers and the physical access to MPs can be examined from constitutional aspects. If this area is too far away or too small (cf. the Hungarian National Assembly), it may cause an unjustified limitation on the interest in parliamentary access. In the parliament there might be "too many" journalists theoretically, which can reach a disturbing level, to this, however a limitation on the number of press accreditations by editorial offices issued (cf. Sejm) cannot be an adequate response, but the number of journalist access (determined for each editorial office or on the basis of an absolute number) may be limited.

Media workers need to accept reasonable limitations, which also come from their professional standards, similarly, MPs need to tolerate journalists' uncomfortable questionings. Feeling indignant at journalists "hovering around" cannot be justified by the protection of the parliament's prestige. This, however, derives not from the human dignity and placidity of MPs but from the operation of the Parliament corresponding with its constitutional function and democratic basis.

\section{References}

9/2013. számú házelnöki rendelkezés az Országház és az Országgyúlés Irodaháza, valamint az Országgyúlés Hivatalának elhelyezésére szolgáló épületek területére történő belépés és az ott-tartózkodás, valamint az Országgyúlési Ôrség e feladatkörével összefüggő tevékenysége részletes szabályairól, online: http://www.parlament.hu/ documents/10181/11066/2013r09.pdf/1940811a-f4bd-44b4-95fc-871924b07a28.

Act XXXVI of 2012 on the National Assembly, online: http://www.parlament.hu/ documents/125505/138409/Act+XXXVI+of+2012+on+the+National+Assembly/ b53726b7-12a8-4d93-acef-140feef44395.

ANNEX: RULE OF LAW AND HUMAN RIGHTS CONCERNS IN POLAND, online: https:// www.fidh.org/IMG/pdf/annex_to_joint_ngo_letter_to_the_european_commission_on_ poland-16_feb_2017.pdf.

Association of European Journalists - In Poland, media freedom fears persist as new plans restricting journalists' access to parliament to be unveiled in January, online: http://www. aej.org/page.asp?p_id=569.

A sajtótudósítás rendje - Országgyúlés, online: http://www.parlament.hu/a-sajtotudositasrendje.

BEYME, Klaus von: Die parlamentarische Demokratie. Entstehung und Funktionweise 1789-1999, Wiesbaden 1999. 
Case of Selmani and Others v. the former Yugoslav Republic of Macedonia, Par. [5]-[15], [16]-[23], [67], online: http://hudoc.echr.coe.int/eng\#\{"itemid":["001-170839"]\}.

HABERMAS, Jürgen: The Structural Transformation of the Public Sphere. An Inquiry into a Category of Bourgeois Society, Cambridge - Massachusetts 1991.

Helsińska Fundacja Praw Człowieka - HFHR on still unclear rules for media in Parliament, online: http://www.hfhr.pl/en/hfhr-on-still-unclear-rules-for-media-in-parliament/.

Itthon: Kitiltották a hvg.hu munkatársát a Parlamentböl, online: http://hvg.hu/ itthon/20160426_Kitiltottak_a_hvghu_munkatarsat_a_Parlamentbol.

KEANE, John: Media and Democracy, Budapest 1999.

Kuchciński zamknął Sejm dla obywateli. Nie wejdą na najbliższe posiedzenie, online: https:// oko.press/kuchcinski-zamknal-sejm-obywateli-wejda-najblizsze-dla-posiedzenie/.

MAGIERA, Siegfried: Art. 42 [Öffentlichkeit, Mehrheitsprinzip, Berichterstattung], in: Grundgesetz Kommentar, SACHS, Michael, München 2011, 1253-1258.

MARKECHOVA, Jana: Act on Slovak Radio and Television, online: http://merlin.obs.coe. int/iris/2011/2/article39.en.html.

MCKAY, William - JOHNSON, Charles W.: Parliament and Congress: Representation and Scrutiny in the Twenty-First Century, Oxford 2012.

Nowe Centrum Medialne, online: http://www.sejm.gov.pl/media8.nsf/files/EPIAAGMN5J/\%24File/Informacja\%20na\%20temat\%20zmian\%20w\%20organizacji\%20 pracy\%20medi\%C3\%B3w\%20w\%20Parlamencie.pdf.

Opinia Helsińskiej Fundacji Praw Człowieka w sprawie założeń zmiany organizacji pracy mediów w Sejmie, online: http://www.hfhr.pl/wp-content/uploads/2017/01/Opinia_ HFPC_11012017.pdf.

Polish protesters block parliament over press freedom - BBC News, online: http://www. bbc.com/news/world-europe-38347674.

POLYÁK, Gábor: Párhuzamos valóságok. Az Alkotmánybíróság nyilvánosság- és médiaképe társadalomtudományi eredmények tükrében [Parallel realities. The publicity and media through the eyes of the Constitutional Court, in the context of the achievements of social sciences], in: Fundamentum, 16, 2012, 4, 24.

Pontosan ennyi lehetőség van politikusokat kérdezni anélkül, hogy Kövér László kitiltana, online: https://444.hu/2016/04/26/pontosan-ennyi-lehetoseg-van-politikusokat-kerdeznihogy-kover-laszlo-ne-tiltson-ki.

SCOTT, Paul: (Political) Constitutions and (Political) Constitutionalism, in: German Law Journal, 12, 2013, 2164.

SMUK, Péter: Ellenzéki jogok a parlamenti jogban [Rights of the opposition in parliamentary law], Budapest 2008.

SMUK, Péter: A politikai diskurzusok alkotmányjogi szerkezete [The structure of political discourses from the perspective of constitutional law], Budapest 2014.

Statement by the Marshal of the Sejm of the Republic of Poland on the course of the 33 ${ }^{\text {rd }}$ sitting of the Sejm on 16 December 2016, online: http://www.sejm.gov.pl/sejm8.nsf/ komunikat.xsp?documentld=4F557DA5DFD6BCA3C1258092002B3A9C.

SZCZERBIAK, Aleks: How will Poland's parliamentary crisis develop? - The Polish Politics Blog, online: https://polishpoliticsblog.wordpress.com/2017/01/03/how-will-polandsparliamentary-crisis-develop/. 
TAMÁS, Fábián: Fidesz: Az újságírók magatartása méltatlan az állampolgárokkal szemben [Fidesz: Journalists' behaviour is unworthy to citizens], online: https://index.hu/ belfold/2016/04/27/partok_es_a_parlamenti_sajtoszabadsag/.

The Fundamental Law of Hungary, online: http://www.parlament.hu/documents/125505/ 138409/Fundamental+law/73811993-c377-428d-9808-ee03d6fb8178.

The Gallery Today - The Parliamentary Press Gallery, online: https://www.pressgallery.org. uk/the-gallery-today/.

The Polish Government's response to the concerns expressed in relation to the proposal of changes to the rules governing journalists' work in the Sejm and Senat, online: https:// rm.coe.int/16806d8de4.

ZARZĄDZENIE NR 1 MARSZAŁKA SEJMU z dnia 9 stycznia 2008 r. w sprawie wstępu do budynków pozostających w zarządzie Kancelarii Sejmu oraz wstępu i wjazdu na tereny pozostające w zarządzie Kancelarii Sejmu, online: http://www.sejm.gov.pl/kancelaria/ zarz1_2008.pdf.

\section{Author}

prof. Péter Smuk PhD.

Alkotmányjogi és Politikatudományi Tanszék, Deák Ferenc Állam- és Jogtudományi Kar,

Széchenyi István Egyetem

Department of Constitutional Law and Political Sciences, Deák Ferenc Faculty of Law and Political Sciences, Széchenyi István University

Áldozat u. 12, 9026 Győr, Hungary

smuk.peter@sze.hu 